\title{
ELECTRICAL LOAD SURVEY AND FORECAST FOR A DECENTRALIZED HYBRID POWER SYSTEM AT ELEBU, KWARA STATE, NIGERIA
}

\author{
A. S. Oladeji1,* and B. F Sule ${ }^{2}$ \\ 1,2 NATIONAL CENTRE FOR Hydropower RESEARCH AND DEV., UNIV. OF ILORIN, ILORIN, KWARA STATE. NIGERIA \\ E-mail addresses:1akinsun3k@yahoo.co.uk, ${ }^{2}$ bfsuleiman@gmail.com
}

\begin{abstract}
This paper presents electrical load survey and forecast for a typical off-grid rural decentralized hybrid power generating systems of a rural area (Elebu). With the data available, energy demand and forecast for ten years was estimated. It was also observed that this community has potential for small hydro, wind and solar energy which can be integrated to meet the present and future energy needs of this area in a cost effective and sustainable manner. The paper reports the results of electrical load demand and forecast for Elebu rural community located in Kwara State, Nigeria. The expected peak load in first year of operation was estimated as $40.18 \mathrm{~kW}$ which will increase every year. The maximum estimated demand at the end of tenth year is about $57 \mathrm{~kW}$. This simply means that the installed capacity would not have been $57 \mathrm{~kW}$ if the maximum estimated demand is $57 \mathrm{~kW}$. On the eleventh year, the demand would have exceeded the installed capacity, thereby making the system unstable and unreliable.
\end{abstract}

Keywords: hybrid system, renewable energy, optimization, electrical energy, load survey and forecasts

\section{INTRODUCTION}

A report released by the World Bank and some foreign organization has shown that Nigeria is taking the ignominious position of the second country with the highest electricity deficit having 82.4 million Nigerians that lack access to electricity [1]. Without access to electricity, the poor are deprived of the most basic economic opportunities they need to improve their standard of living among other benefits. Due to their geographical location and the lack of critical mass, rural areas are mainly suitable for renewable energy off-grid applications, such as connection to a battery via a charge controller, which stores the electricity generated and acts as the main power supply [2,3]. Access to electricity is still a dream for $20 \%$ of the world's population. Most of the people (about $85 \%$ ) are living in rural areas where the extension of utility grid is either complex or very expensive [3]. The International Energy Agency (IEA) foresees that if current policies do not change by 2030 there will still be 1.2 billion people without access to electricity [4]. Nearly all of the regions in Nigeria are endowed with abundant renewable energy resources. such resources as solar energy, biomass, wind, small and large hydroelectric with potential for hydrogen fuel, geothermal and ocean energies [5]. These potentials remain largely untapped. The average solar radiation ranges between $3.5-7.0 \mathrm{kWh} / \mathrm{m}^{2} /$ day, annual wind speed ranges between $2-4 \mathrm{~m} / \mathrm{s}$ at a height of $10 \mathrm{~m}$, identified small hydropower has a potential of 735MW [5]. Nigeria is divided into eight hydrological areas. The total numbers of existing and proposed dams in each of the hydrological areas is 428 [6]. Majority of these dams are for single purpose (water supply or irrigation) and they have inherent potential for power generation which can be used by rural communities [6]. Nigeria has huge oil and gas reserves of about 37 billion barrels and 187 Tscf (Trillions of standard cubic feet of gas), respectively; and the largest oil producer and exporter in Africa [5]. But the reserves of fossil fuels are impossible to sustain the sustainable development in the future. The National Energy Policy (NEP) articulates Nigerian energy vision and sets out a road map for the use of all viable energy sources for sustainable national development [7].

The issue of climate change and global warming arising from the increasing consumption of conventional fuels coupled with environmental degradation has led to the development of environment-friendly renewable energy sources. 
Exploitation of renewable sources of energy is imperative to mitigate energy crisis and eventually substitute environmental degradation (due to burning of fossil fuels) in foreseeable future [8]. Often, the cost of connection to the grid in remote locations cannot be justified [9]. The socio-economic development of rural areas in Nigeria could not take place even after more than 50 years of independence, as the grid could not be extended to those areas due to the high cost of transmission and distribution of electrical energy, scattered nature of the area and low load factor. In this situation, the possible solution is the adoption of a hybrid energy system. This system combines two or more renewable sources along with a back-up source depending on the availability of resources and load demand in those remote areas $[3,10]$. Combining these renewable energy sources with back-up units to form a hybrid system can provide a more economic, environment friendly and reliable supply of electricity in all load demand co nditions than to single-use of such. [11].The required power for the connected loads can be effectively delivered and supplied by a hybrid Power Generation/Energy Storage System (PG/ESS) with appropriate control and effective coordination among various subsystems [12]. The integrated approach makes a hybrid system to be the most appropriate for isolated communities of a rural area $[3,13]$.Depending upon the topography of the area, energy resources potential available, type of energy needs/demand and socioeconomic status of remote areas, the energy models can be developed and optimized in order to suit the needs of the area [14]. Renewable energy technologies avoid greenhouse emissions, have low operation and maintenance costs, generate employment and allow decentralized production of the rural areas. In rural areas, they are capable of electrifying homes, villages, farms and small industries as well as being used for telecommunication, water supply and irrigation [3]. The basic objectives of the development of renewable energy is ensuring energy security and reducing emissions. In a series of case studies, the keys to achieving successful electrification programs for remote and off-grid locations are: strong political will, substantive funding, integrated development planning, and innovative off-grid technologies [15]. This paper investigates the electrical load survey and forecast for a typical off-grid rural area, Elebu in Kwara State of Nigeria. Elebu is chosen for a decentralized hybrid power generating systems based on the available renewable energy resources.

\section{HYBRID POWER SYSTEM}

The performance of hybrid system is dependent on the environmental conditions [3]. Several studies have been carried out on hybrid power generation systems over the year based on available resources. The concept of small-scale decentralized Integrated Renewable Energy System (IRES)which considered Solar Photo Voltaic (SPV), solar thermal, wind, biomass and falling water as renewable resources have been discussed by [16]. A methodology was also developed to design IRES using a linear programming (LP) approach, which minimizes an objective function of total annual cost, subject to a set of energy and power constraints [17]. A mathematical approach was used in a simple and useful form and is directly applicable for the design of stand-alone IRES for rural area of developing countries. Further [18] used the concept based on an appropriate combination of solar, wind and biomass systems and proved that IRES is a reliable and viable concept from energy production and utilization point of view. It was established in [19] that IRES can play significant role in meeting the energy need of a rural area and for improving the living conditions of the people. It was observed that the concept of energization through resource-need matching has been found to be preferable as compared to straightforward rural electrification. An optimal renewable energy model (OREM) was developed by [20], which minimized the cost/efficiency ratio with the social acceptance, resource limitation, and demand and reliability factors used as constraints. About 38 different renewable energy options were considered in the model.

A simulation tool (prepared in simulink) for designing hybrid systems and micro grids was developed [21]. Optimization of PV-Wind-Hydro-Diesel Hybrid System by minimizing excess capacity and cost of energy was presented in [22]. Three demand loads were used in the simulation using HOMER to find the optimum combination and sizing of components. Another set of demand loads was used to investigate the effect of reducing the demand load against the dominant power provider of the system. The results showed that the cost of energy can be reduced to about $50 \%$ if the demand load is increased to the maximum capacity. Reducing the load to the capacity of the dominant power provider will reduce the cost of energy by $90 \%$. The design idea of optimized Solar-Wind Hybrid Energy System for GSM/CDMA type mobile based station over conventional diesel generator for a particular site in central India (Bhopal) was proposed 
in [23]. Based on simulation and optimization results acquired using HOMER software, it was shown that the system is more cost effective and environmental friendly over the conventional diesel generator. It could reduce approximately by $70-80 \%$ fuel cost over conventional diesel generator and also reduced the emission of $\mathrm{CO}_{2}$ and other harmful gases in environment. In [24], a cost effective design of off-grid wind-diesel hybrid power system using combined heat and power technology in a grid isolated island, Sandwip, Bangladesh was presented. Detailed economic analysis and comparison with solar PV clearly revealed that wind-diesel hybrid power system can be a cost effective solution for the isolated island like Sandwip. A stand- alone electrical supply system which combined the output of wind and solar photovoltaic generating systems was described in [25]. The experimental system comprised of wind and solar collectors, each of $5 \mathrm{~kW}$ rating, with a lead acid battery for storage and a $10 \mathrm{~kW}$ PWM inverter for the final output. For all load demands the levelised energy cost for PV-wind hybrid system was found to be always lower than that of stand -alone solar PV or wind system. [26]Discussion of the optimization of PV/Wind/Micro-Hydro/Diesel Hybrid Power System in HOMER for the study area was presented in [26]. The HOMER software was used to study and design the proposed hybrid alternative energy power system. Based on simulation results, it was found that renewable/alternative energy sources will replace the conventional energy sources and would be a feasible solution for distribution of electric power for standalone applications at remote and distant locations. Feasibility study of stand- alone solar-wind hybrid power system with the objective to maximize use of renewable energy generation system while minimizing the total system cost was carried out in [27].

The literature reveals that very little work has been reported on integration of micro-hydropower with other sources. Since the larger percentage of off-grid locations in the country (Nigeria) are rich in hydro resources, it was considered worthwhile to develop and optimize IRES models consisting of microhydropower, solar and wind energy for the purpose of providing affordable, reliable and efficient electricity to off-grid areas in the country. Moreover, there is no single hybrid power generating system in the country presently.

\section{DESCRIPTION OF THE STUDY AREA}

The study area is Elebu, Moro Local Government, Kwara State, Nigeria. The total population of Moro was about 108, 792 as at 2006 Census. The study area, Elebu community is a complete off-grid location which is not connected to Nation's National Grid. It has about two hundred (200) households, forty-eight (48) houses, one community health centre and one government primary school.

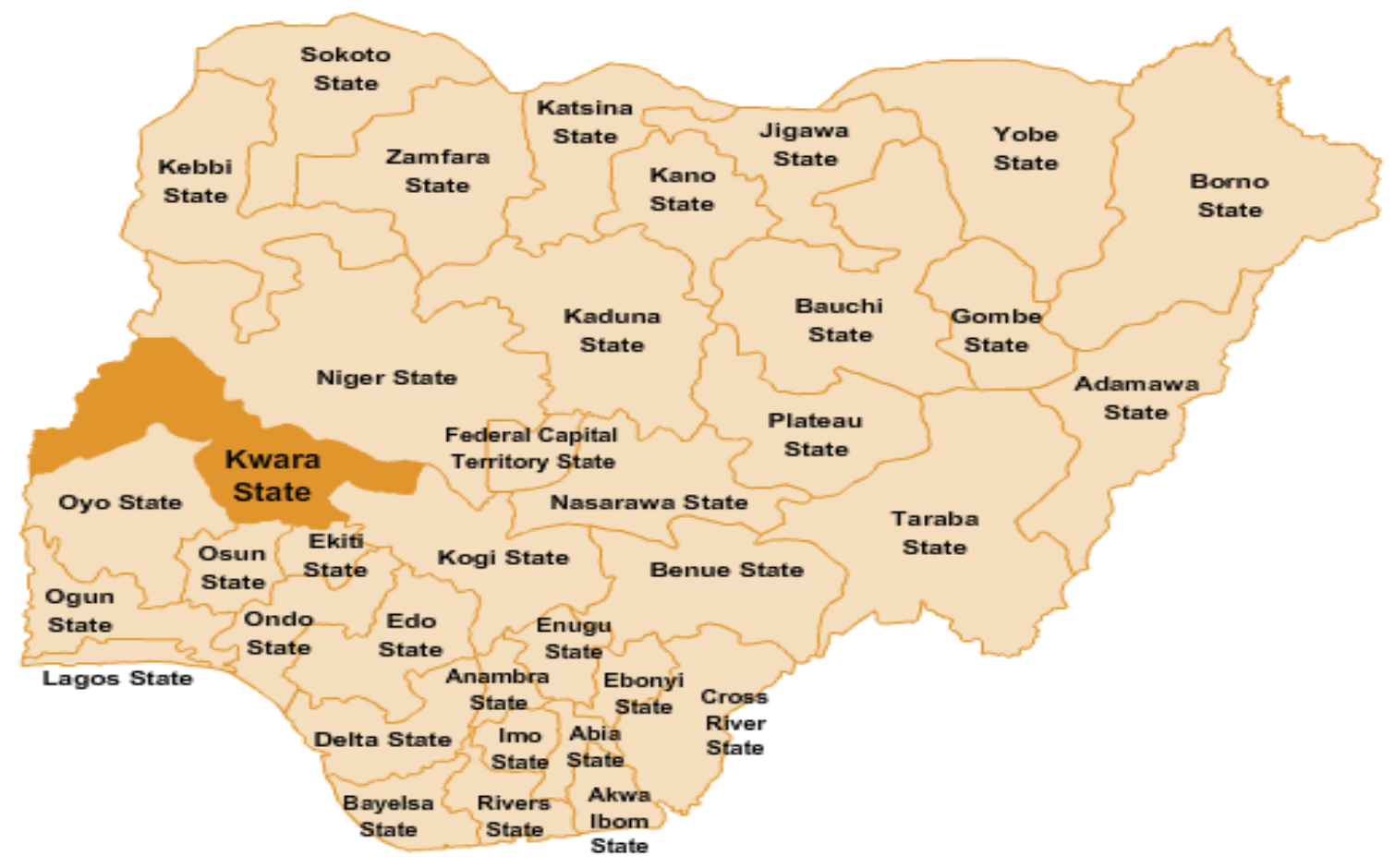

Figure 1: Map of Nigeria Showing Location of Kwara State [28] 


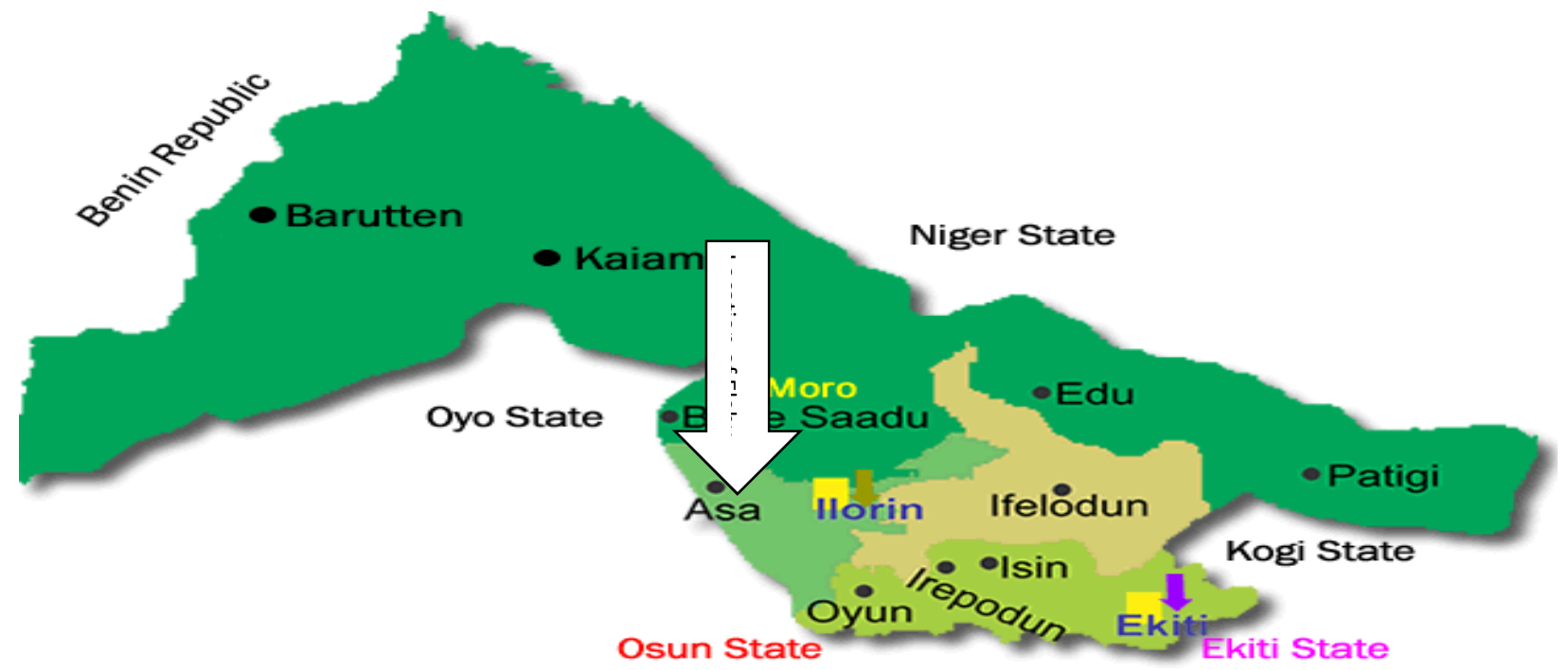

Figure2: Map of Kwara State Showing Location of Moro Local Government [29]

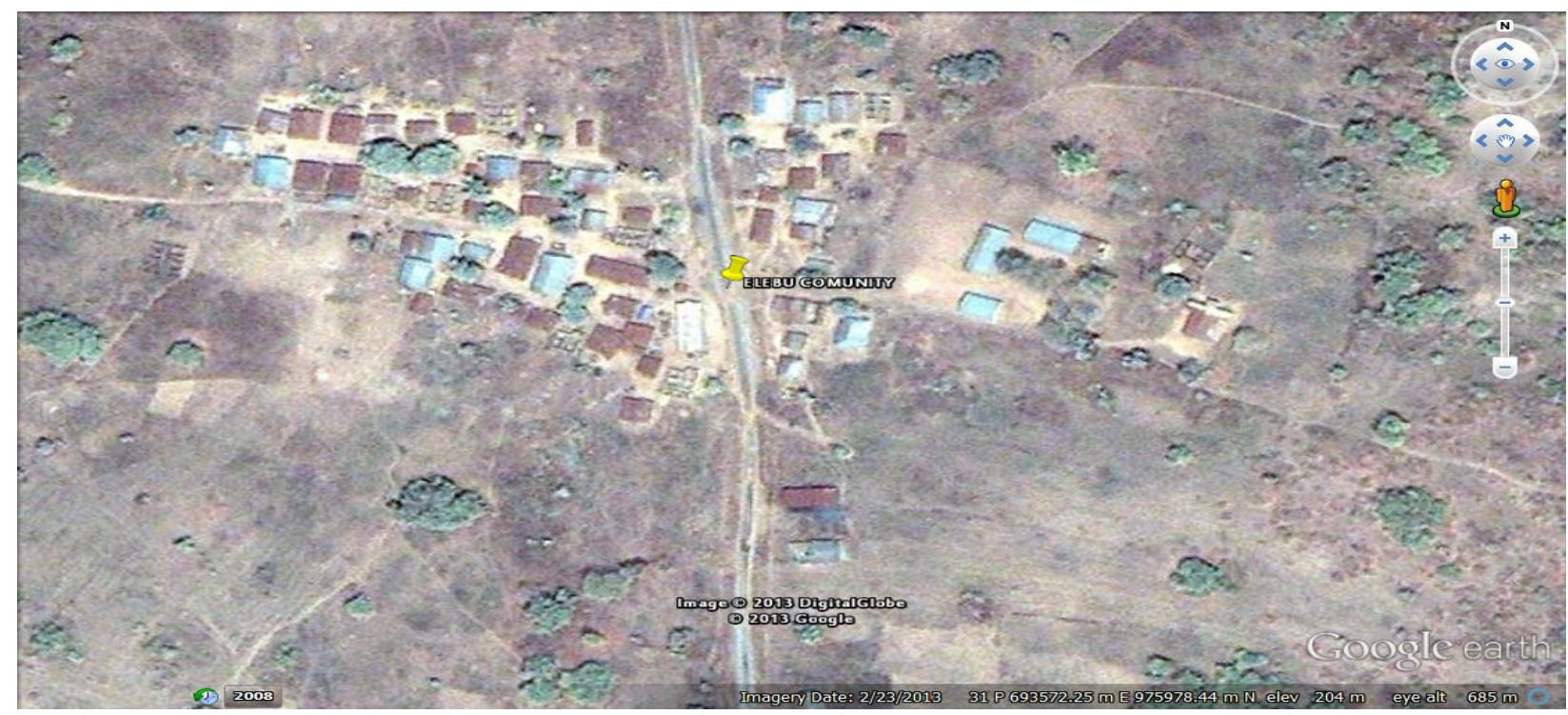

Figure3: Google Image of the Study Area (Elebu, Moro Local Government, Kwara State, Nigeria)

These data are based on the results of electrical load survey conducted by the centre (National Centre for Hydropower Research and Development, University of Ilorin) on $31^{\text {st }}$ October, 2013. The primary source of energy is fuel wood for cooking and secondary source is kerosene for lighting and security. Agriculture and animal husbandry are significant commercial activities in the area. The main crops grown are corn, millet, yam, beans and cassava. The study area is rich in hydro, solar and wind renewable resources. The geographical location of study area is ( $8^{0} 49^{\prime} 31.66^{\prime \prime} \mathrm{E}, 4^{0} 45^{\prime}$ $\left.35.33^{\prime \prime} \mathrm{N}\right)$ and that of hydro resource is $\left(8^{0} 49^{\prime} 14.42^{\prime \prime} \mathrm{E}\right.$, $4045^{\prime} 39.55^{\prime \prime} \mathrm{N}$ ) while the straight distance between the study area and the hydro resource within the area is approximately $572 \mathrm{~m}$. The map of Nigeria showing the location of Kwara State is shown in Figure1 while map of Kwara state showing the location of Moro Local
Government is shown in Figure 2.The google imagery of the study area showing the total number of houses is shown in Figure 3.

\section{LOAD FACTOR}

The ratio of average load to the maximum demand during a certain period of time such as a day or a month or a year is called the load factor. Since average load is always less than the maximum demand, load factor is therefore, always less than unity. For the load forecast, knowledge of load factor is necessary. The load factor may be daily or monthly or annually.

$$
\text { Load factor }=\frac{\text { Average Demand }}{\text { Maximum Demand }}
$$




$$
\begin{aligned}
\text { Load factor }=\frac{\text { Units generated in a given period }}{\text { Maximum demand } \times \text { numer of hours of operation in a given period }} \\
\qquad \begin{aligned}
\text { Annual load factor } & =\frac{\text { number of units actually supplied in a year }}{\text { maximum number of units that can be supplied }} \\
& =\frac{\text { number of units actually supplied in a year }}{\text { maximum power demand } \times 365 \times 24} \\
& =\frac{\text { number of units actually supplied in a year }}{\text { maximum power demand } \times 8760}
\end{aligned}
\end{aligned}
$$

Maximum power demand means the value of the connected peak load and not the maximum $\mathrm{kW}$ installed capacity of the hybrid generating power station. The installed capacity of the hybrid power generating station should be such that it will be the peak load demand.

\section{ELECTRICAL LOAD SURVEY AND FORECAST}

For the power evacuation, knowledge of the power demand of villages to be electrified is needed. In the present work, this was estimated through interviews of the village head, school teachers, farmers, etc. The following factors were considered during the electrical load survey of the study area for the location of the proposed hybrid power system.

- Population

- Number of houses

- Number of households

- Average daily electrical energy consumption

- Number of schools, health centres and their energy demand
- Miscellaneous demand

- Demand for street lighting

\subsection{Load Estimation and Demand}

The data obtained are based on the results of electrical load survey conducted by the National Centre for Hydropower Research and Development, University of Ilorin on $31^{\text {st }}$ October, 2013. The primary load is residential with some load for health centre and schools. As at the time of the survey, there was no industrial or commercial load demand. The load is composed of the household devices such as lighting points, fans, TVs and radios. Note that refrigerators, ironing devices and other heavy electric equipment are not included in the calculation for houses and schools. The estimated energy consumed by each of the categories is shown in Table 1 . The table shows estimation of each appliance's rated power, its quantity and the hours of use by each house, health centre, streetlights and school in a single day. The

\begin{tabular}{|c|c|c|c|c|c|c|}
\hline Type of Consumers & Load Type & Rated Power (W) & Quantity & Hours & $\begin{array}{l}\text { Energy } \\
\text { (Wh/Day) }\end{array}$ & Total Energy (kWh/day) \\
\hline Residential & TV & 80 & 1 & 9 & 720 & \\
\hline \multirow[t]{4}{*}{ (Per Household) } & Radio & 15 & 1 & 7 & 105 & \\
\hline & CFL & 20 & 3 & 5 & 300 & 2.01 \\
\hline & Fan & 80 & 1 & 5 & 400 & \\
\hline & Miscellaneous & 20 & 1 & 24 & 480 & \\
\hline \multirow[t]{4}{*}{ Health Centre } & Refrigerator & 100 & 1 & 8 & 800 & \\
\hline & CFL & 20 & 4 & 6 & 480 & 2.48 \\
\hline & TV & 80 & 1 & 9 & 720 & \\
\hline & Miscellaneous & 20 & 1 & 24 & 480 & \\
\hline \multirow[t]{3}{*}{ School } & CFL & 20 & 10 & 7 & 1400 & \\
\hline & Fan & 80 & 10 & 7 & 5600 & 7.48 \\
\hline & Miscellaneous & 20 & 1 & 24 & 480 & \\
\hline Street Lighting & CFL & 36 & 30 & 10 & 10800 & 10.80 \\
\hline
\end{tabular}
miscellaneous load is for unknown loads in each category.

Table 1: Load Types and Estimation

Note: CFL is the Compact Fluorescent Lamp, and TV is Television 
Table 2: Load Demand for Various Types of Consumers

\begin{tabular}{|c|c|c|c|c|}
\hline $\begin{array}{l}\text { Type of } \\
\text { Consumers }\end{array}$ & $\begin{array}{c}\text { Average Daily } \\
\text { Consumption } \\
\text { (kWh) }\end{array}$ & $\begin{array}{l}\text { Present Number of } \\
\text { Consumers }\end{array}$ & $\begin{array}{l}\text { Per Annual Increase in } \\
\text { Consumption (\%) }\end{array}$ & $\begin{array}{c}\text { Number of New } \\
\text { Consumers Per Year }\end{array}$ \\
\hline Residential & 2.010 & 200 & 5 & 10 \\
\hline School & 7.480 & 1 & 5 & \\
\hline Health Centre & 2.480 & 1 & 5 & \\
\hline Street Lighting & 0.360 & 30 & & 5 \\
\hline
\end{tabular}

Table 3: Load Forecast of Proposed Hybrid Power Generating Station for Ten Years

\begin{tabular}{|c|c|c|c|c|c|c|c|c|c|c|c|}
\hline S/N. & $\begin{array}{l}\text { Category of } \\
\text { Consumer }\end{array}$ & $\begin{array}{c}\text { IYr. } \\
\times \mathbf{1 0}^{\mathbf{3}} \mathrm{kWh} \\
\end{array}$ & $\begin{array}{c}\| Y Y_{.} \times \\
\mathbf{1 0}^{3} \mathrm{kWh} \\
\end{array}$ & $\begin{array}{l}\text { III Yr. X } \\
\mathbf{1 0}^{3} \mathrm{kWh} \\
\end{array}$ & $\begin{array}{l}\text { IV Yr. X } \\
\mathbf{1 0}^{3} \mathrm{kWh} \\
\end{array}$ & $\begin{array}{c}\text { VYr. } \times \\
10^{3} \mathrm{kWh} \\
\end{array}$ & $\begin{array}{l}\text { VI Yr. } \times \\
\mathbf{1 0}^{3} \mathrm{kWh} \\
\end{array}$ & $\begin{array}{l}\text { VIIIr. X } \\
\mathbf{1 0}^{3} \mathrm{kWh} \\
\end{array}$ & $\begin{array}{l}\text { VIIII Yr. } \times \\
\mathbf{1 0}^{3} \mathrm{kWh} \\
\end{array}$ & $\begin{array}{l}\text { IXYr.X } \\
\mathbf{1 0}^{3} \mathrm{kWh} \\
\end{array}$ & $\begin{array}{c}\text { XYr. } \times \\
\mathbf{1 0}^{3} \mathrm{kWh} \\
\end{array}$ \\
\hline 1. & Residential & 147 & 162 & 178 & 194 & 211 & 229 & 248 & 267 & 288 & 308 \\
\hline 2. & Primary School & 2.88 & 3.00 & 3.14 & 3.28 & 3.41 & 3.55 & 3.69 & 3.82 & 3.96 & 4.10 \\
\hline 3. & Health Centre & 0.91 & 0.95 & 1.00 & 1.04 & 1.09 & 1.13 & 1.18 & 1.22 & 1.27 & 1.31 \\
\hline 4. & Street Light & 3.94 & 4.60 & 5.26 & 5.91 & 6.57 & 7.23 & 7.88 & 8.54 & 9.20 & 9.86 \\
\hline 5. & Miscellaneous & 5.00 & 6 & 7 & 8 & 9.00 & 10.00 & 11.00 & 12.00 & 13.00 & 14.00 \\
\hline 6. & $\begin{array}{l}\text { Sub-Total ( } 1 \text { to } \\
5)\end{array}$ & 159.7 & 176.6 & 194.4 & 212.2 & 231.1 & 250.9 & 271.8 & 292.6 & 315.4 & 337.3 \\
\hline 7. & $\begin{array}{l}\text { Transmission \& } \\
\text { distribution } \\
\text { losses (10\% of } \\
\text { (6) ) }\end{array}$ & 15.97 & 17.66 & 19.44 & 21.22 & 23.11 & 25.09 & 27.18 & 29.26 & 31.54 & 33.73 \\
\hline 8. & $\begin{array}{c}\text { Energy } \\
\text { demand at bus } \\
\text { bar }(7+6)\end{array}$ & 175.69 & 194.26 & 213.83 & 233.42 & 254.21 & 275.99 & 298.98 & 321.86 & 346.94 & 371.03 \\
\hline 9. & Approximation & 176.00 & 194.00 & 214.00 & 233.00 & 254.00 & 276.00 & 299.00 & 322.00 & 347.00 & 371.00 \\
\hline 10. & $\begin{array}{l}\text { Load Factor } \\
\text { (Assumed) }\end{array}$ & 0.5 & 0.55 & 0.60 & 0.65 & 0.70 & 0.71 & 0.72 & 0.73 & 0.74 & 0.75 \\
\hline 11. & $\begin{array}{l}\text { Peak Load } \\
\text { (Maximum } \\
\text { Demand in kW) } \\
\text { Equation (6) }\end{array}$ & 40.18 & 40.27 & 40.72 & 40.92 & 41.42 & 44.38 & 47.41 & 50.35 & 53.53 & 56.47 \\
\hline
\end{tabular}

\subsection{Results for Load Demand and Forecasting}

The data obtained from load survey are used to design the daily energy demand for a period of ten years as shown in the Table 2 .

\subsection{Calculation for Maximum Demand}

Calculation for maximum demand in each year is given by:

maximum demand $=$

number of units actually supplied in ayear

$\overline{\text { Load factor } \times 8760 \text { (Number of hours in a year) }}$

A load forecast table was prepared as given in Table 3. In this table, it is assumed that transmission and distribution losses are $10 \%$ of the total consumptions. The load factor is also assumed for each year. The consumption of electrical power by various types of consumers are calculated on the basis of above data shown in Table 2.

\section{FURTHER RESEARCH AND DEVELOPMENT WORKS}

(i) Assessment of renewable energy resources potential at the proposed site, i.e. measurement of solar insulation data $\left(\mathrm{kWh} / \mathrm{m}^{2} /\right.$ day $)$, measurement of wind speed and direction $\left(\mathrm{m} / \mathrm{s}^{2}\right)$ and measurement of hydrological data (discharge $\mathrm{m}^{3} / \mathrm{s}$ ).

(ii) Development of a model to evaluate suitable technology options based on cost and availability of resources using appropriate optimization technique. Comparison of the results with other available optimization software like LINDO, LINDO API, LINGO, HOMER, VIPOR, TORA, etc.,

(iii) Construction of the hybrid power system (the development of wind-small hydrosolar hybrid energy generating system) at the proposed site

(iv) Study the power quality issues of the constructed hybrid power generating system

\section{CONCLUSION}

An electrical load survey and forecast has been conducted for the typical rural off-grid community, 
(Elebu) located in Kwara State, Nigeria for the pilot study of hybrid power generating system using available renewable energy resources. The expected peak load in first year of operation is estimated to be $40.18 \mathrm{~kW}$ which is expected to be increasing every year. The maximum demand at the end of tenth year would be about $57 \mathrm{~kW}$. This simply means that if the installed capacity of the proposed hybrid power generating system is $57 \mathrm{~kW}$, then it will operate up to ninth under its capacity and from tenth year onward it will operate at is installed capacity. The survey could be useful in the design of hybrid power system. The results show that the installed capacity should not be more than $60 \mathrm{~kW}$. This will keep the cost of civil works and electromechanical system very reasonable and affordable.

\section{ACKNOWLEDGEMENTS}

Funding for this Research project was provided by the National Centre for Hydropower Research and Development (NACHRED), University of Ilorin, Nigeria. The authors wish to thank NACHRED for providing funding for this project.

\section{REFERENCES}

[1] Premium Newspaper June $4^{\text {th }} 2013$, http://pmnewsnigeria.com/2013/06/04

[2] Renewable Global Status Report 2006 Update REN21 published 2006, accessed $16^{\text {th }}$ May 2007

[3] Anil K. S., Arun M. S.,Bhardwaj S. K. 'Forecasting and Management of road for Rural Areas'. International Journal of Scientific and Research Publications, Volume 3, Issue 1, January 2013, pp. 1-6.

[4] Olatz A., Iñaki A. and Itziar Z. "Rural Electrification based on renewable Energies. A Review", International Conference on Renewable Energies and Power Quality(ICREPQ'12), Spain, March 2012, pp. 16.

[5] Sambo A.S., "The Participation of State Governments in the Power Sector: Matching Supply with Demand", Ladi Kwali Hall, Sheraton Hotel and Towers, Abuja. 29th July, 2008, accessed $11^{\text {th }}$ May 2014 http://sammyshow.expertscolumn.com/article/mat ching-electricity-supply-demand-nigeria

[6] Sule B.F.,' Small Hydropower: An Experiment on Water Wheel Technology for Rural Communities' in proc. International conference on renewable energyKatsina 2012", Umaru Musa Yar'adua University, Katsina, 3rd -5th September 2012, pp. 921-948 http://www.umyu.edu.ng/Conference\%20Proceedi ng_ISSCERER_KT_2012.pdf
[7] Energy Commission of Nigeria, 'National Energy Policy $2005^{\prime}$.

[8] S.M. Shaahid, M.A. Elhadidy, 'Economic analysis of hybrid photovoltaic-diesel-battery power systems for residential loads in hot regions-A step to clean future'. Renewable and Sustainable Energy Reviews, 12 (2008), pp. 488-503.

[9] Muralikrishna M. and Lakshminarayana V. 'A $10 \mathrm{~kW}$ Combined Hybrid (Wind and Solar Photovoltaic) Energy Systems for Isolated Generating System'. ARPN Journal of Engineering and Applied Sciences, Vol. 6, No. 6, June 2011, pp. 99-104.

[10] Rajoriya A. \& Fernandez E. "Sustainable energy generation using hybrid energy system for Remote hilly rural area in India", International Journal of Sustainable Engineering, Vol. 3, No. 3, Sept. 2010, pp. 219-227.

[11] Erdinc 0., Uzunoglu M.' Optimum design of hybrid renewable energy systems: Overview of different approaches.' Renewable and Sustainable Energy Reviews, 16 (2012), pp. 1412- 1425.

[12] Li W., Dong-Jing L., Wei-Jen L., Zhe C. 'Analysis of a novel autonomous marine hybrid power generation/energy storage system with a highvoltage direct current link'. Journal of Power Sources, 185 (2008), pp. 1284-1292.

[13] Gupta A., Saini R. P. and Sharma M. P. "Design of an Optimal Hybrid Energy System Model for Remote Rural Area Power Generation", Proceedings of the International Conference on Electrical Engineering (ICEE), Lahore, Apr. 2007, pp. 1-6.

[14] Akella A.K., Sharma M.P., Saini R.P. "Optimum Utilization of Renewable Energy Sources in a Remote Area", Renewable and Sustainable Energy Reviews, 2007, pp. 894-908.

[15] Ester M. 'Renewable Energy, Off-Grid Power \& Energy Efficiency in Nigeria'. Paper presented at the Nigeria Power Sector Retreat, Abuja, 21 st January, 2012, accessed 11 th June, 2013http://www.giz.de/en/downloads/giz2014-ennigerian-energy-sector.pdf.

[16] Ramakumar R. 'Renewable energy sources and developing countries'. IEEE Trans Power Appar Syst, PAS-102(2):502-510 1983.

[17] Jain B.C.' Rural energy centres based on renewablecase study on an effective and viable alternative. IEEE Trans Energy Converse EC-2(3): 1987, pp. 329-35.

[18] Ramakumar R., Shetty P.S., Ashenayi K. 'A linear programming approach to the design of integrated renewable energy systems for developing countries'. IEEE Trans Energy Conversion EC-1(4): 1986, pp. 1824.

[19] Ramakumar R. 'Energizing rural areas of developing countries using IRES'. IEEE Trans Energy Conversion, 1996, pp. 1536-1541.

Vol. 34. No. 3, July 2015 
[20] Iniyan S., Jagadeesam T.R., "On the development of reliability based optimal renewable energy model for the sustainable energy scene in India", Int Journal of Ambient Energy18(3): 1997, pp. 153-164.

[21] Piotr B. and Marcin K. "Design of Power Plant Capacity in DC Hybrid System and Microgrid”, ecology vehicle renewable energy, Monaco, March 26-29, 2009, pp. 1-9.

[22] Juhari Ab., Kamaruzzaman S., Yusoff A., Mohammad A. A., Azami Z., Ibrahim A., "Optimization of PV-WindHydro-Diesel Hybrid System by Minimizing Excess Capacity" European Journal of Scientific Research, Vol.25 No.4, 2009, pp. 663-671.

[23] Pragya N., Nema R.K., Saroj R. "PV-solar/ wind hybrid energy system for GSM/CDMA Type mobile telephony base station", international journal of energy and environment, Vol.1, Issue 2, 2010, pp.359-366.

[24] Nahid-A., Rifat M., Jubaer A., Amina H. A., Deeba S.R., Faeza H., Mahmuda B. and Chowdhury A. H. "Design of Cost Effective Off-Grid Wind-Diesel Hybrid Power System in an Island of Bangladesh", World Academy of Science, Engineering and Technology 60 ,2011, pp.312 -315.

[25] Muralikrisha M. and Lakshminarayana V. "A 10kW Combined Hybrid (Wind and Solar Photovoltaic) Energy Systems for Isolated Generating System", ARPN, Journal of Engineering and Applied Sciences vol. 6, no.6, June 2011, pp.99-104.

[26] Deepak K.L., Bibhuti D.B., Akella A.K, “Optimization of PV/Wind/Micro-Hydro/Diesel Hybrid Power System in HOMER for Study Area" International Journal on Electrical Engineering and Informatics, vol. 3, 2011, pp.307-325.

[27] Parita G.D., Chintan M.R.," Feasibility Study of SolarWind-Hybrid Power System", International journal of emerging technology and advanced engineering, Vol.2 issue 3, March 2012, pp. 125128. www.ijetae.com.

[28] http://ynaija.com/politico/kwaralgelection-7things-you-should-know-about-the-state-and-theelections-today/accessed 10 th May, 2011.

[29] http://www.safinngo.org/ our\%20communities. $\underline{h t m}$ accessed $10^{\text {th }}$ June, 2012. 